\title{
Large-Scale Yielding Failure Prediction of Notched Ductile Plates by Means of the Linear Elastic Notch Fracture Mechanics
}

\author{
A. R. Torabi, ${ }^{a}$ A. Campagnolo, ${ }^{b}$ and F. Berto ${ }^{\mathrm{c}, \mathrm{d}, 1}$ \\ a Fracture Research Laboratory, Faculty of New Sciences \& Technologies, University of Tehran, \\ Tehran, Iran \\ ${ }^{\mathrm{b}}$ Department of Industrial Engineering, University of Padova, Padova, Italy \\ ${ }^{c}$ Department of Management and Engineering, University of Padova, Vicenza, Italy \\ d Department of Mechanical and Industrial Engineering, Norwegian University of Science and \\ Technology (NTNU), Trondheim, Norway \\ ${ }^{1}$ filippo.berto@ntnu.no
}

УДК 539.4

\section{Прогнозирование разрушения при полномасштабном течении в пласти- нах с надрезом на основе линейной упругой механики разрушения}

\author{
А. Р. Тораби ${ }^{\mathrm{a}}$, А. Кампаньоло ${ }^{6}$, Ф. Берто ${ }^{\mathrm{B}, \mathrm{\Gamma}}$ \\ a Лаборатория исследования разрушения, Факультет инновационных технологий, Тегеранский \\ университет, Тегеран, Иран \\ ${ }^{\sigma}$ Факультет организации производства, Падуанский университет, Падуя, Италия \\ в Факультет менеджмента и инжиниринга, Падуанский университет, Виченца, Италия \\ г Механико-машиностроительный факультет, Норвежский университет естественных и техни- \\ ческих наук, Тронхейм, Норвегия
}

Предложен критерий разрушения, основанный на линейной упругой механике разрушения, для прогнозирования инициирования трещчины растяжения от затупленного V-образного надреза при большой пластичности вблизи надреза. Описаны некоторые современнье экспериментальные результаты по разрушению при растяжении пластичных алюминиевых пластин с V-образным надрезом. С иелью избежания сложного и трудоемкого упругопластического анализа для прогнозирования несущей способности алюминиевых пластин с V-образным надрезом используются концепция эквивалентного материала и критерий усредненной плотности энергии деформащчи, базирующийся на линейной упругой механике разрушения. Показано хорошее соответствие между экспериментальными данными и результатами прогнозирования на основе концепции эквивалентного материала и критерия усредненной плотности энергии деформации.

Ключевые слова: надрез, пластичный материал, зарождение трещины, понятие эквивалентного материала, критерий усредненной плотности энергии деформации, полномасштабное течение.

Introduction. In general, ductile metallic materials are divided into two main categories. The first and second categories involve those materials exhibiting negligible and considerable strain-hardening in the plastic zone, respectively. An accurate factor to realize the category is normally the difference between the yield and tensile strengths of the material. The fracture mechanics analyses for the two categories are really different. The 
materials inside the first category have usually valid fracture toughness value in the context of the linear elastic fracture mechanics (LEFM); i.e., $K$-based fracture toughness $K_{\text {Ic }}$ or $K_{c}$, where $K_{\mathrm{I} c}$ is utilized in plane-strain conditions, which is usually satisfied for relatively large thicknesses, and $K_{c}$ in plane-stress conditions, relating to small thicknesses. For ductile metallic materials inside the second category, a LEFM-based fracture toughness, $K_{\mathrm{I} c}$ or $K_{c}$, is not obtained according to the standard code ASTM E399-12e3 [1], but instead, some other fracture toughness values in the context of the elastic-plastic fracture mechanics (EPFM), e.g., the crack tip opening displacement (CTOD), crack tip opening angle (CTOA), resistance curve ( $R$-curve), critical $J$-integral, etc., are utilized to characterize the resistance of material against crack propagation [2,3]. Despite valid $K_{\mathrm{I} c}$ or $K_{c}$ values for the first category, if the size of the plastic zone ahead of the crack tip at the propagation instance becomes considerable, particularly for small thicknesses, the effects of the plastic zone on the prediction of crack propagation should be considered in the fracture models.

Although the physical meaning of the notch fracture toughness (NFT) is completely different from that of the fracture toughness (FT); the NFT means the resistance of a notch against initiating $\operatorname{crack}(\mathrm{s})$ from its border, while the FT means that of a crack against propagation; the failure process in notched members is very similar to that in cracked ones. For example, in a V-notched ductile member, a plastic region initiates from the notch border during loading and grows till the onset of crack initiation from the notch border at which the notched member shows its load-carrying capacity (LCC). For predicting the LCC of a V-notched ductile component, various criteria exist depending on the existence of valid or invalid $K$-based fracture toughness value. For ductile materials inside the first category, the thickness of the notched component plays an important role in selecting appropriate failure criteria. If the thickness becomes larger than a specified value, which is usually computable, no considerable plastic zone will form around the notch at the crack initiation instance and hence, the failure criteria in the context of the linear elastic notch fracture mechanics (LENFM) can accurately be utilized for the LCC prediction. For small thicknesses (e.g., thin plates), however, the plastic zone size is significant; so considering the effects of plastic deformations around the notch in the LCC prediction is necessary, and using directly the LENFM-based criteria is not allowable.

Aluminum alloys are extensively utilized in engineering structures, particularly aerospace structures, due to their good strength/weight ratio, high toughness and ductility, good fatigue resistance and fracture toughness etc. Most of such alloys locate inside the first category of ductile materials and hence, they have valid values of $K$-based fracture toughness. Consequently, selecting the failure criterion for predicting the NFT for such alloys strongly depends on thickness. Recently, two papers have been published on the NFT of aluminum alloys $[4,5]$. The mode I NFT of a commercial aluminum alloy containing U-notches of various tip radii has been evaluated by Vratnica et al. [4]. They have carried out the fracture experiments on $10 \mathrm{~mm}$ thick single-edge-notched-bend (SENB) specimens; measured the NFT, and predicted successfully the experimentally obtained NFT values by means of a stress-based criterion that employs the linear-elastic stress distributions around a blunt crack-like notch [4]. Madrazo et al. [5] have also performed a research work on mode I fracture of notched Al 7075-T651 specimens. They have conducted tensile fracture tests on the notched compact-tension (CT) specimens of $20 \mathrm{~mm}$ thick and experimentally measured the mode I NFT values [5]. Such values have then been well predicted by means of the linear elastic theory of critical distances (TCD) [5]. It is worth noting that the TCD has two well-known approaches, namely the point method and the line method [6-9] which both have been employed in [5] for theoretical fracture assessments. According to the requirements reported in [1] for a valid $K_{\mathrm{Ic}}$ test and considering the materials tensile and fracture toughness properties reported in $[4,5]$; the minimum thicknesses for valid fracture toughness tests can simply be calculated to be equal to about 40 and $5 \mathrm{~mm}$, respectively. 
Comparing theses values with the notched specimen thicknesses reported in $[4,5]$ indicates that the notched specimens of [4] do not satisfy plane-strain conditions, while those of [5] do so. Accordingly, considerable plastic zone has been formed around notches of [4] at the crack initiation instance and hence, ignoring such a zone in the theoretical failure predictions is questionable.

Most recently, due to wide application of thin aluminum plates in aero-structures, a few research works have been carried out on ductile failure analysis of thin notched aluminum plates under various loading conditions [10-15]. In [10-15], Torabi and co-researchers have performed numerous failure tests on thin rectangular plates weakened by blunt V- and U-notches, and made of the aluminum alloys Al 7075-T6 and Al 6061-T6 under pure mode I and mixed mode I/II loading conditions from which the cracking behavior of the plates has been studied; the failure regime, e.g., the moderate-scale yielding (MSY), large-scale yielding (LSY) etc., has been determined; and the LCC of the notched plates has been experimentally measured. As observed during the experiments, for such thin plates, the plastic zone around the notch at the crack initiation instance is considerable and hence, the failure criteria in the context of the LENFM could not be used for predicting the LCC of the notched plates. In order to avoid time-consuming and complex elastic-plastic failure analyses and to make the LENFM-based failure criteria usable for such ductile problems, the equivalent material concept (EMC), proposed originally by the first author [16-19], has been employed. The experimentally obtained LCCs have been successfully predicted by using some well-known stress-based brittle fracture criteria, namely the point-stress (PS), mean-stress (MS) and maximum tangential stress (MTS) criteria together with the EMC [10-15].

The most recent research on ductile failure of notched components has been performed by Torabi et al. [20]. In [20], the experimentally recorded tensile LCCs of the V-notched Al 7075-T6 plates reported in [10] have been well predicted by means of the EMC in conjunction the well-known energy-based brittle fracture criterion, namely the averaged strain energy density (ASED) criterion [21-27]. It has been found in [20] that the EMC-ASED criterion could work well on mode I ductile failure of notched aluminum plates under the MSY failure regime. In order to examine the success of the EMC-ASED criterion also under the LSY failure regime, it is attempted in the present research to predict the tensile LCCs of the V-notched Al 6061-T6 plates reported most recently in [14]. A very good agreement is shown to exist between the theoretical and experimental results, demonstrating that the combination of the EMC and the ASED criterion is successful, regardless of the size of plastic zone around the notch at crack initiation instance.

1. Ductile Fracture Test Results Reported in the Literature. Most recently, Torabi and Keshavarzian [14] have published a set of ductile fracture test results on blunt V-notched thin plates under pure mode I loading. The material investigated has been the aluminum alloy Al 6061-T6 with the chemical composition and mechanical properties presented in Tables 1 and 2, respectively [14]. Figure 1 shows the tensile engineering and true stress-strain curves of the material [14]. As seen in Fig. 1, Al 6061-T6 exhibits ductile behavior in tension with negligible strain-hardening in the plastic region.

$\mathrm{T}$ a b 1 e 1

Al 6061-T6 Chemical Composition [14] (in wt.\%)

\begin{tabular}{|c|c|c|c|c|c|c|c|c|c|c||}
\hline $\mathrm{Si}$ & $\mathrm{Fe}$ & $\mathrm{Cu}$ & $\mathrm{Mn}$ & $\mathrm{Mg}$ & $\mathrm{Zn}$ & $\mathrm{Ni}$ & $\mathrm{Cr}$ & $\mathrm{Pb}$ & $\mathrm{Sn}$ & $\mathrm{Ti}$ \\
\hline 0.61 & 0.48 & 0.17 & 0.05 & 0.86 & 0.02 & 0.003 & 0.2 & 0.001 & 0.001 & 0.08 \\
\hline $\mathrm{B}$ & $\mathrm{Cd}$ & $\mathrm{Bi}$ & $\mathrm{Ca}$ & $\mathrm{P}$ & $\mathrm{Sb}$ & $\mathrm{V}$ & $\mathrm{Zr}$ & $\mathrm{Co}$ & $\mathrm{Li}$ & $\mathrm{Al}$ \\
\hline 0.004 & 0.001 & 0 & 0.001 & 0.002 & 0.008 & 0.025 & 0.0002 & 0.003 & 0.001 & 97.6 \\
\hline
\end{tabular}


$\mathrm{T}$ a b 1 e 2

Some of the Mechanical Properties of Al 6061-T6 [14]

\begin{tabular}{||l|c||}
\hline \multicolumn{1}{|c|}{ Mechanical property } & Value \\
\hline Elastic modulus $E, \mathrm{GPa}$ & 67 \\
Poisson's ratio & 0.33 \\
Tensile yield strength $(\mathrm{MPa})$ & 276 \\
Ultimate tensile strength $(\mathrm{MPa})$ & 292 \\
Elongation at break $(\%)$ & 11 \\
Engineering strain at maximum load & 0.034 \\
True fracture stress $(\mathrm{MPa})$ & 299 \\
Fracture toughness $K_{c}, \mathrm{MPa} \sqrt{\mathrm{m}}$ & 38 \\
Strain-hardening coefficient $(\mathrm{MPa})$ & 314 \\
Strain-hardening exponent & 0.021 \\
\hline
\end{tabular}

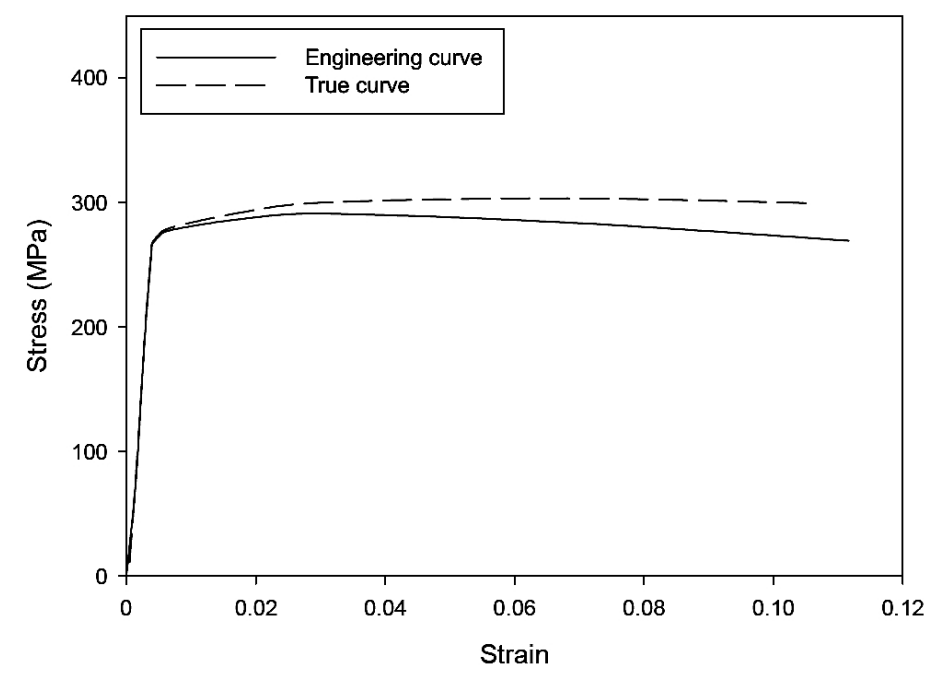

Fig. 1. Tensile engineering and true stress-strain curves of Al 6061-T6 [14].

The specimen utilized in [14] to perform the fracture experiments has been a rectangular plate of $4 \mathrm{~mm}$ thick containing a centrally located rhombic slit with four round-tip V-notches; two of which are subjected to pure mode I loading (i.e., the opening mode) as a result of a tensile load remotely applied to the specimen. A scheme of the specimen is depicted in Fig. 2, including the geometrical and loading parameters [14].

The parameters $2 \alpha, \rho, 2 a, L, W$, and $P$ in Fig. 2 are the notch angle, the notch radius, twice the notch length (i.e., the horizontal diameter of the rhombic slit), the specimen length, the specimen width, and the applied tensile load, respectively. The specimen dimensions have been considered in the fracture tests to be as follows: $2 \alpha=30$, 60, and $90^{\circ}, \rho=1,2$, and $4 \mathrm{~mm}, 2 a=25 \mathrm{~mm}, L=160 \mathrm{~mm}$, and $W=50 \mathrm{~mm}$ [14]. Totally, twenty seven displacement-controlled monotonic fracture tests have been conducted in [14].

Three experimentally obtained evidences have been reported in [14], demonstrating that the V-notched Al 6061-T6 plates have failed by the LSY regime. Note that the failure has been defined in [14] to be the crack initiation from the notch tip. The evidences are: (i) permanent deformations of the specimen ligament in large amount at the crack initiation instance (it could be captured by naked eye); (ii) considerable opening of the notch mouth 
before failure, and (iii) large nonlinear portion in the load-displacement curve before the peak. To numerically confirm the experimentally observed LSY failure of the V-notched Al 6061-T6 plates, some elastic-plastic finite element (FE) analyses have been performed on the plates, and it has been shown that a large portion of the ligament (more than $50 \%$ ) experiences plastic deformations at the onset of crack initiation from the notch tip, proving well the LSY failure regime [14].

The experimental values of the LCC of the tested specimens reported in [14] are summarized in Table 3 for various notch angles and notch radii. In Table 3, the parameter $P_{i}(i=1,2,3)$ denotes the LCC in the three repeated tests and $P_{a v}$ is the average of the three LCCs.

$\mathrm{T}$ a $\mathrm{b} 1$ e 3

Experimental LCCs of the V-Notched Al 6061-T6 Specimens for Various Notch Angles and Notch Radii [14]

\begin{tabular}{||c|c|c|c|c|c||}
\hline $2 \alpha, \mathrm{deg}$ & $\rho, \mathrm{mm}$ & $P_{1}, \mathrm{~N}$ & $P_{2}, \mathrm{~N}$ & $P_{3}, \mathrm{~N}$ & $P_{a v}, \mathrm{~N}$ \\
\hline 30 & 1 & 30,567 & 30,350 & 29,997 & 30,305 \\
& 2 & 31,674 & 31,884 & 31,913 & 31,824 \\
& 4 & 31,862 & 31,615 & 31,652 & 31,710 \\
\hline 60 & 1 & 31,325 & 31,685 & 31,876 & 31,629 \\
& 2 & 31,668 & 31,538 & 31,711 & 31,639 \\
& 4 & 32,119 & 31,869 & 31,946 & 31,978 \\
\hline 90 & 1 & 29,334 & 30,626 & 30,114 & 30,025 \\
& 2 & 31,501 & 31,468 & 31,485 & 31,485 \\
& 4 & 31,516 & 31,398 & 31,450 & 31,455 \\
\hline
\end{tabular}

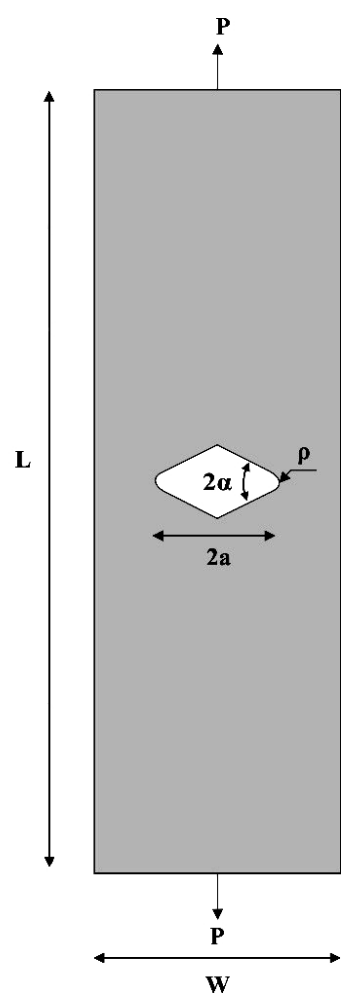

Fig. 2. Scheme of the test specimen including the geometrical and loading parameters [14]. 
In the next section, the EMC is briefly described, capable of equating the real ductile material having elastic-plastic behavior with a virtual brittle material exhibiting linearelastic behavior.

2. Equivalent Material Concept. The EMC has been originally proposed by Torabi [16] with the aim to take a permission to analyze ductile failure of notched members by means of the LENFM principles. Two main mechanical properties, namely the fracture toughness and the tensile strength are necessary for failure analysis of notched components in the context of the LENFM. For the first property, it is assumed that the ductile material showing considerable plastic zone in the tensile stress-strain curve has valid $K$-based fracture toughness $\left(K_{\mathrm{I} c}\right.$ or $\left.K_{c}\right)$ value. For the second property, the ultimate tensile strength of the ductile material cannot directly be used in the LENFM-based fracture criteria, since the material exhibits considerable nonlinear behavior in the plastic region. To overcome this restriction, the EMC is utilized in which the ductile material is equated with a virtual brittle material with linear elastic behavior; both absorb the same amount of the tensile strain energy density (SED) for the crack initiation to take place. By computing the SED for ductile material till the ultimate point and setting it equal to that for the virtual brittle material till final fracture, the tensile strength of the equivalent material can be computed.

Considering the power-law relationship between the stress and the plastic strain in the plastic region of the ductile material, an expression has been reported in a few recent references for computing the tensile strength of the equivalent material, $\sigma_{f}^{*}$. It is [10-15]:

$$
\sigma_{f}^{*}=\sqrt{\sigma_{Y}^{2}+\frac{2 E K}{n+1}\left[\varepsilon_{u, t r u e}^{n+1}-(0.002)^{n+1}\right]}
$$

where the parameters $\sigma_{f}^{*}, \sigma_{Y}, E, K, n$, and $\varepsilon_{u, t r u e}$ are the tensile strength of the equivalent material, yield strength of the real ductile material (e.g., Al 6061-T6 in [14]), elastic modulus, strain-hardening coefficient, strain-hardening exponent, and the true plastic strain at maximum load, respectively. Simply, $\varepsilon_{u, t r u e}$ can be calculated by using Eq. (2), in which the parameter $\varepsilon_{u}$ denotes the engineering plastic strain at maximum load:

$$
\varepsilon_{u, \text { true }}=\ln \left(1+\varepsilon_{u}\right) \text {. }
$$

Now, the $K_{\mathrm{Ic}}$ (or $K_{c}$ ) and $\sigma_{f}^{*}$, which are the two main fracture properties of the equivalent material, can simply be utilized in various fracture criteria in the field of the LENFM, e.g., the ASED criterion, for predicting the onset of crack initiation from the notch tip in ductile materials. In the forthcoming sections, the ASED criterion is briefly described and by linking it to the EMC [i.e., using $K_{\mathrm{I} c}$ (or $K_{c}$ ) and $\sigma_{f}{ }_{f}$ values in the criterion], the tensile LCCs of the V-notched Al 6061-T6 plates (see Table 3) that fail by LSY regime are theoretically predicted.

3. Brief Description of the ASED Criterion. The most important point for designers is certainly the existence of appropriate failure models to predict the load-carrying capacity of components weakened by notches. With the aim to provide such models, a strain energy density based criterion has been proposed by Lazzarin and co-authors [21, 22], by which the experimental fracture loads of notched specimens can properly be estimated.

The strain energy density factor $S$ was defined for sharp cracks by Sih [28] as the product of the strain energy density by a specified critical distance measured from the crack tip. Fracture was thought of as controlled by a critical value $S_{c}$, whereas the crack growth direction was determined by imposing a minimum condition on the factor $S$. 
The method proposed by Sih is a point-wise criterion, while the ASED approach as presented in $[21,22]$ suggests that brittle fracture takes place when the strain energy density averaged over a known control volume is equal to a critical value $W_{c}$. This value varies from material to material but it is independent of the notch geometry. The control volume is thought of as dependent on the ultimate tensile strength and on the fracture toughness $K_{\text {Ic }}$ in the case of brittle or quasi-brittle materials subjected to static and monotonic loads. Such a method was formalized and applied first to sharp V-notches under mode I and mixed mode I/II loadings [21] and later extended to blunt U- and V-notches [22, 29], also under multiaxial I/III static loadings [24, 25]. Some recent developments and applications are reported in $[22,30-32]$, with some considerations also to three-dimensional effects [33-35], which have been widely discussed in [36].

For sharp cracks, the control volume is a circle of radius $R_{c}$ centered at the crack tip (Fig. 3a). Under plane-strain conditions, the critical length, $R_{c}$, can be evaluated by the following expression [37]:

$$
R_{c}=\frac{(1+v)(5-8 v)}{4 \pi}\left(\frac{K_{\mathrm{I} c}}{\sigma_{t}}\right)^{2} .
$$

In Eq. (3), $K_{\mathrm{I} c}$ is the fracture toughness, $v$ is Poisson's ratio, and $\sigma_{t}$ is the ultimate tensile strength of the material.

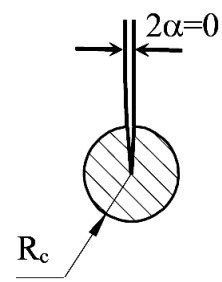

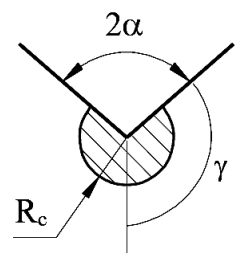

$\mathrm{b}$

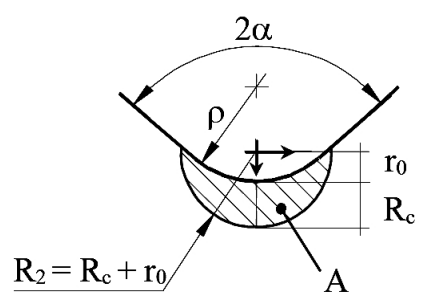

C

Fig. 3. Control volume (area) for sharp crack (a), sharp V-notch (b) and blunt V-notch (c) under mode I loading. Distance $r_{0}=\rho(\pi-2 \alpha) /(2 \pi-2 \alpha)$.

For a sharp V-notch, the control volume becomes a circular sector of radius $R_{c}$ centered at the notch tip (Fig. 3b), while for a blunt V-notch under mode I loading, the volume assumes the crescent shape, as shown in Fig. 3c, where $R_{c}$ is the depth measured along the notch bisector line. The outer radius of the crescent shape is equal to $R_{c}+r_{0}$, being $r_{0}$ the distance between the notch tip and the origin of the local coordinate system (see Fig. 3c). Such a distance depends on the V-notch opening angle $2 \alpha$, according to the expression $r_{0}=\rho(\pi-2 \alpha) /(2 \pi-2 \alpha)$. For more details see also [22].

4. Application of EMC in Combination with ASED Criterion. The ASED approach is applied here by considering the mechanical properties of the equivalent material. The critical strain energy density, $W_{c, E M C}$, is evaluated by using Eq. (4) and considering $\sigma_{f}^{*}=1066 \mathrm{MPa}$, as obtained by applying the EMC according to Eq. (1):

$$
W_{c, E M C}=\frac{\left(\sigma_{f}^{*}\right)^{2}}{2 E} .
$$

The critical strain energy density results to be equal to $8.48 \mathrm{MJ} / \mathrm{m}^{3}$. The control radius $R_{c}$ is evaluated by using Eq. (3) with $\sigma_{t}=\sigma_{f}^{*}=1066 \mathrm{MPa}$. It has been found $R_{c}=$ $=0.317 \mathrm{~mm}$. 
The ASED occurring inside the control volume embracing the edges of V-notches, $\bar{W}$, is calculated numerically by using the FE code ANSYS®. For each geometry, a model is created which requires an accurate definition of the control volume where the ASED should be averaged (see Fig. 3c). All FE analyses are performed by using second order eight-node plane elements (PLANE 183 of the ANSYS ${ }^{\circledR}$ element library) under plane-strain conditions. A detail of the FE mesh adopted inside the control volume is reported in Fig. 4. In particular, typical refined and coarse FE meshes are shown in Fig. 4a and 4b, respectively. As it is well-known from [30-32, 38, 39], the ASED can correctly be evaluated also with very coarse FE meshes and, for this reason, all numerical models are performed here using the FE mesh shown in Fig. 4b.

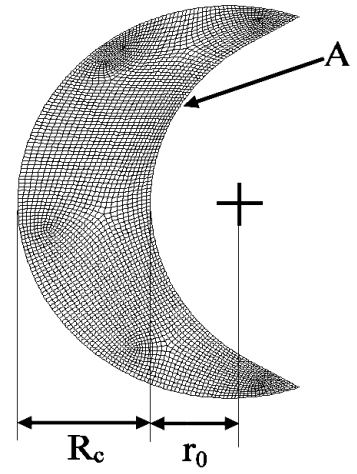

a

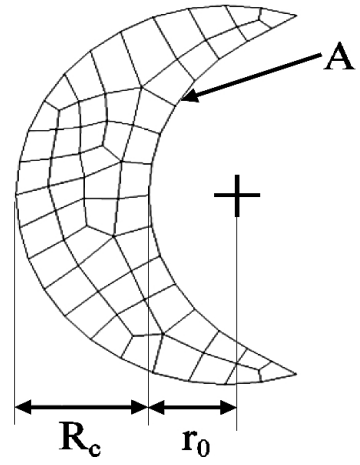

b

Fig. 4. Example of the refined FE mesh employed in the control volume (a). The same results can be achieved by using a coarse FE mesh, as that shown in (b).

5. Results and Discussion. Table 4 summarizes the outlines of the experimental, numerical and theoretical findings for V-notched specimens with three different notch radii ( $\rho=1,2$, and $4 \mathrm{~mm}$ ) and opening angles $\left(2 \alpha=30,60\right.$, and $\left.90^{\circ}\right)$, analyzed by means of the ASED approach. In particular, Table 4 reports the experimental loads to failure $(P)$ for all notch radii $\rho$ and opening angles $2 \alpha$ compared with the theoretical values $\left(P_{A S E D}\right)$, obtained on the basis of the ASED evaluation. $P_{A S E D}$ is the theoretical load obtained by keeping a constant averaged strain energy density $(\bar{W})$ equal to $8.48 \mathrm{MJ} / \mathrm{m}^{3}$, that is the material critical value, over the control volume.

The last columns of the table present the deviations between the values of the experimental failure loads and the theoretical ones evaluated by means of ASED criterion. $\Delta$ is defined as the ratio between the experimental load and the theoretical one for each case.

It is clearly seen in Table 4 that the great majority of predictions are well inside the scatter of $\pm 20 \%$, with some results inside the scatter $\pm 10 \%$. Only few exceptions are characterized by a deviation between 20 and $25 \%$.

A synthesis in terms of the square root value of the local strain energy averaged over the control volume of radius $R_{c}$ (namely, $\bar{W}$ ), normalized with respect to the critical energy of the equivalent material, $W_{c, E M C}$, as a function of the notch opening angle $2 \alpha$ is shown in Fig. 5. The plotted parameter is proportional to the failure load. The aim is to investigate the influence of the notch geometry on the fracture prediction based on the ASED approach. Also from the graphical point of view, it is obvious that most of values fall inside a scatter ranging from 0.80 to 1.20 with the majority of the data inside 0.90 to 1.10. Only few exceptions are outside the scatter band, having a normalized ASED between 
$\mathrm{T}$ a b 1 e 4

Critical Loads Predicted by Means of ASED Criterion in Combination with EMC

\begin{tabular}{||c|c|c|c|c|c|c|c|c||}
\hline $2 \alpha$, deg & $\rho, \mathrm{mm}$ & $P_{1}, \mathrm{~N}$ & $P_{2}, \mathrm{~N}$ & $P_{3}, \mathrm{~N}$ & $P_{A S E D}, \mathrm{~N}$ & $\Delta_{1}$ & $\Delta_{2}$ & $\Delta_{3}$ \\
\hline 30 & 1 & 30,567 & 30,350 & 29,997 & 31,711 & 0.96 & 0.96 & 0.95 \\
& 2 & 31,674 & 31,884 & 31,913 & 35,951 & 0.88 & 0.89 & 0.89 \\
& 4 & 31,862 & 31,615 & 31,652 & 42,518 & 0.75 & 0.74 & 0.74 \\
\hline \multirow{2}{*}{60} & 1 & 31,325 & 31,685 & 31,876 & 29,943 & 1.05 & 1.06 & 1.06 \\
& 2 & 31,668 & 31,538 & 31,711 & 34,349 & 0.92 & 0.92 & 0.92 \\
& 4 & 32,119 & 31,869 & 31,946 & 41,092 & 0.78 & 0.78 & 0.78 \\
\hline \multirow{3}{*}{90} & 1 & 29,334 & 30,626 & 30,114 & 28,559 & 1.03 & 1.07 & 1.05 \\
& 2 & 31,501 & 31,468 & 31,485 & 32,465 & 0.97 & 0.97 & 0.97 \\
& 4 & 31,516 & 31,398 & 31,450 & 39,009 & 0.81 & 0.80 & 0.81 \\
\hline \hline
\end{tabular}

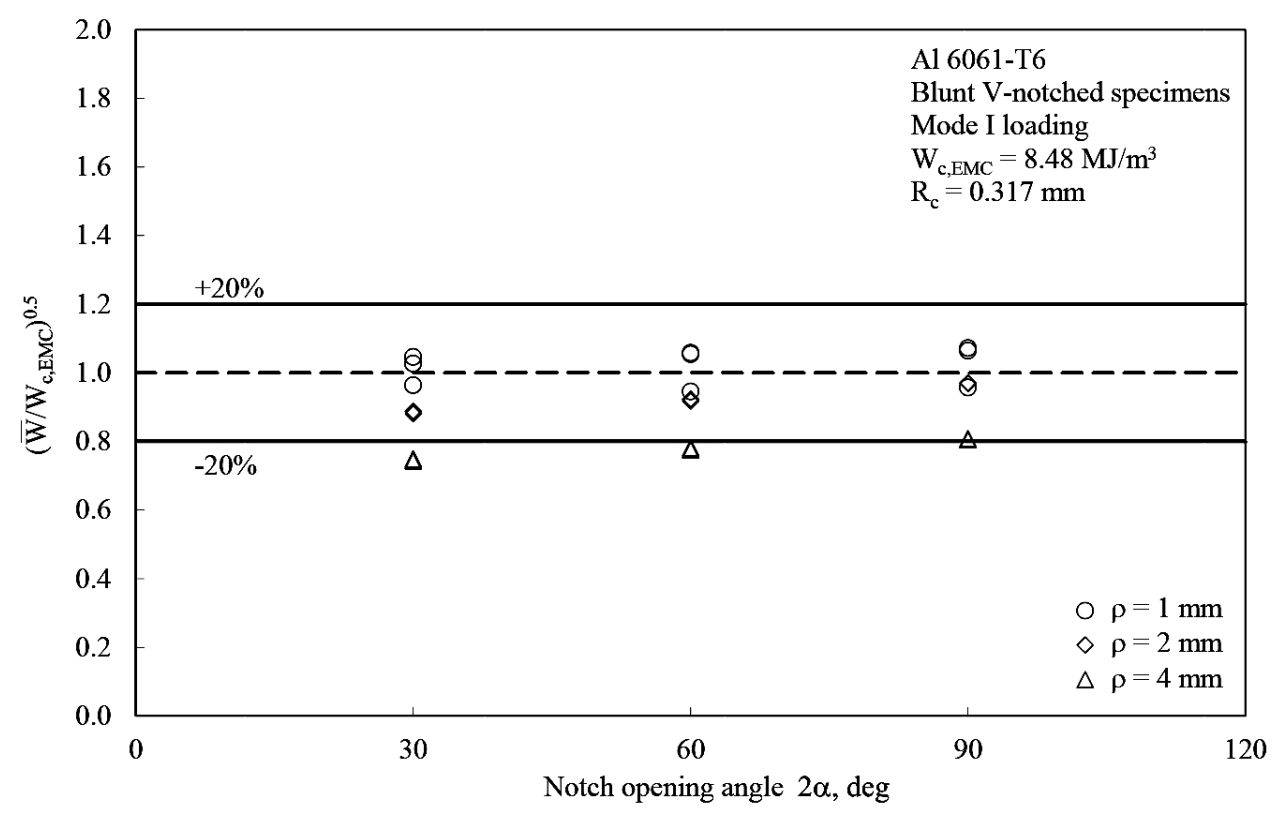

Fig. 5. Synthesis of fracture data in terms of normalized ASED.

0.75 and 0.80 . The synthesis confirms also the choice of the control volume, which seems to be suitable to characterize the material behavior under pure mode I loading. The scatter of the experimental data presented here is in very good agreement with the recent database in terms of ASED reported in a recent review of the approach, which dealt with brittle and quasi-brittle materials [22].

Conclusions. The present research is aimed to predict tensile crack initiation in $\mathrm{Al}$ 6061-T6 thin plates weakened by blunt V-notches. Some experimental results relevant to tensile failure of V-notched ductile aluminum plates, published in a recent contribution, were briefly described. In that work, on the basis of experimental observations, a large-scale yielding failure regime was demonstrated for the considered aluminum plates. With the aim of theoretically predicting the experimental results, the equivalent material concept was adopted in conjunction with the averaged strain energy density evaluated over a control volume. Without requiring elastic-plastic finite element analyses, it was shown 
that the combination of the averaged strain energy density approach and the equivalent material concept can successfully predict the load-carrying capacity of the V-notched Al 6061-T6 plates, characterized by large plastic deformations ahead of the notch tip at the onset of crack initiation.

\section{Резюме}

Запропоновано критерій руйнування, що базується на лінійній пружній механіці руйнування, для прогнозування ініціювання тріщини розтягу від затупленого V-подібного надрізу при значній пластичності поблизу надрізу. Описано деякі сучасні експериментальні результати щодо руйнування при розтязі пластичних алюмінієвих пластин із V-подібним надрізом. Із метою запобігання складного і трудомісткого аналізу для прогнозування несівної здатності алюмінієвих пластин із V-подібним надрізом використовуються концепція еквівалентного матеріалу і критерій усередненої щільності енергії деформації, що базується на лінійній пружній механіці руйнування. Показано хороший збіг експериментальних даних із результатами прогнозування на основі концепції еквівалентного матеріалу і критерію усередненої щільності енергії деформації.

1. ASTM E399-12e3. Standard Practice for Linear-Elastic Plane-Strain Fracture Toughness $K_{\mathrm{I} c}$ of Metallic Materials, ASTM International, West Conshohocken, PA (2012).

2. T. L. Anderson, Fracture Mechanics: Fundamentals and Applications, 2nd edn, CRC Press, Boca Raton (1994).

3. A. Saxena, Nonlinear Fracture Mechanics for Engineers, CRC Press, Boca Raton (1998).

4. M. Vratnica, G. Pluvinage, P. Jodin, et al., "Notch fracture toughness of high-strength Al alloys," Mater. Design, 44, 303-310 (2013).

5. V. Madrazo, S. Cicero, and I. A. Carrascal, "On the Point Method and the Line Method notch effect predictions in Al7075-T651," Eng. Fract. Mech., 79, 363-379 (2012).

6. L. Susmel and D. Taylor, "On the use of the Theory of Critical Distances to predict static failures in ductile metallic materials containing different geometrical features," Eng. Fract. Mech., 75, 4410-4421 (2008).

7. D. Taylor, "Predicting the fracture strength of ceramic materials using the theory of critical distances," Eng. Fract. Mech., 71, 2407-2416 (2004).

8. S. Kasiri and D. Taylor, "A critical distance study of stress concentrations in bone," $J$. Biomech., 41, 603-609 (2008).

9. D. Taylor, "The theory of critical distances applied to the prediction of brittle fracture in metallic materials," Struct. Integr. Durab., 1, 145-154 (2005).

10. A. Torabi and M. Alaei, "Application of the equivalent material concept to ductile failure prediction of blunt V-notches encountering moderate-scale yielding," Int. J. Damage Mech., 25, No. 6, 853-877 (2016).

11. A. R. Torabi and M. Alaei, "Mixed-mode ductile failure analysis of V-notched Al 7075-T6 thin sheets," Eng. Fract. Mech., 150, 70-95 (2015).

12. A. R. Torabi, R. Habibi, and B. Mohammad Hosseini, "On the ability of the equivalent material concept in predicting ductile failure of U-notches under moderateand large-scale yielding conditions," Phys. Mesomech., 18, 337-347 (2015). 
13. A. R. Torabi and R. Habibi, "Investigation of ductile rupture in U-notched Al 6061-T6 plates under mixed mode loading," Fatigue Fract. Eng. Mater. Struct., 39, No. 5, 551-565 (2015).

14. A. R. Torabi and M. Keshavarzian, "Tensile crack initiation from a blunt V-notch border in ductile plates in the presence of large plasticity at the notch vicinity," Int. J. Terrasp. Sci. Eng., 8, 93-101 (2016).

15. A. R. Torabi and M. Keshavarzian, "Evaluation of the load-carrying capacity of notched ductile plates under mixed mode loading," Theor. Appl. Fract. Mech., 85, 375-386 (2016).

16. A. R. Torabi, "Estimation of tensile load-bearing capacity of ductile metallic materials weakened by a V-notch: The equivalent material concept," Mater. Sci. Eng. A, 536, 249-255 (2012).

17. A. R. Torabi, "Ultimate bending strength evaluation of U-notched ductile steel samples under large-scale yielding conditions," Int. J. Fracture, 180, 261-268 (2013).

18. A. R. Torabi, "The equivalent material concept: Application to failure of O-notches," Eng. Solid Mech., 1, 129-140 (2013).

19. A. R. Torabi, "On the use of the Equivalent Material Concept to predict tensile load-bearing capacity of ductile steel bolts containing V-shaped threads," Eng. Fract. Mech., 97, 136-147 (2013).

20. A. R. Torabi, F. Berto, and A. Campagnolo, "Elastic-plastic fracture analysis of notched Al 7075-T6 plates by means of the local energy combined with the equivalent material concept," Phys. Mesomech., 19, 204-214 (2016).

21. P. Lazzarin and R. Zambardi, "A finite-volume-energy based approach to predict the static and fatigue behavior of components with sharp V-shaped notches," Int. J. Fracture, 112, 275-298 (2001).

22. F. Berto and P. Lazzarin, "Recent developments in brittle and quasi-brittle failure assessment of engineering materials by means of local approaches," Mater. Sci. Eng. $R$ Reports, 75, 1-48 (2014).

23. A. R. Torabi, A. Campagnolo, and F. Berto, "Tensile fracture analysis of key-hole notches by means of the strain energy density," Strength Mater., 48, No. 2, 259-269 (2016).

24. F. Berto, A. Campagnolo, and M. R. Ayatollahi, "Brittle fracture of rounded V-notches in isostatic graphite under static multiaxial loading," Phys. Mesomech., 18, 283-297 (2015).

25. F. Berto, M. R. Ayatollahi, and A. Campagnolo, "Fracture tests under mixed mode I + III loading: an assessment based on the local energy," Int. J. Damage Mech., doi: $10.1177 / 1056789516628318$ (2016).

26. A. R. Torabi, A. Campagnolo, and F. Berto, "Static strength of V-notches with end holes under combined tension-shear loading: Experimental measurement by the disk test and theoretical prediction by the local energy," J. Test. Eval., 45, doi:10.1520/ JTE20140496 (2017).

27. A. Campagnolo, F. Berto, and D. Leguillon, "Fracture assessment of sharp V-notched components under Mode II loading: a comparison among some recent criteria," Theor. Appl. Fract. Mech., 85, 217-226 (2016).

28. G. C. Sih, "Strain-energy-density factor applied to mixed mode crack problems," Int. J. Fracture, 10, 305-321 (1974). 
29. P. Lazzarin and F. Berto, "Some expressions for the strain energy in a finite volume surrounding the root of blunt V-notches," Int. J. Fracture, 135, 161-185 (2005).

30. G. Meneghetti, A. Campagnolo, F. Berto, and B. Atzori, "Averaged strain energy density evaluated rapidly from the singular peak stresses by FEM: cracked components under mixed-mode (I+II) loading," Theor. Appl. Fract. Mech., 79, 113-124 (2015).

31. A. Campagnolo, G. Meneghetti, and F. Berto, "Rapid finite element evaluation of the averaged strain energy density of mixed-mode (I+II) crack tip fields including the T-stress contribution," Fatigue Fract. Eng. Mater. Struct., 39, No. 8, 982-998 (2016).

32. G. Meneghetti, A. Campagnolo, and F. Berto, "Averaged strain energy density estimated rapidly from the singular peak stresses by FEM: Cracked bars under mixed-mode (I+III) loading," Eng. Fract. Mech., 167, 20-33 (2016).

33. L. P. Pook, A. Campagnolo, and F. Berto, "Coupled fracture modes of discs and plates under anti-plane loading and a disc under in-plane shear loading," Fatigue Fract. Eng. Mater. Struct., 39, No. 8, 924-938 (2016).

34. A. Campagnolo, F. Berto, and C. Marangon, "Cyclic plasticity in three-dimensional notched components under in-phase multiaxial loading at $R=-1$," Theor. Appl. Fract. Mech., 81, 76-88 (2015).

35. C. Marangon, A. Campagnolo, and F. Berto, "Three-dimensional effects at the tip of rounded notches subjected to mode-I loading under cyclic plasticity," J. Strain Anal. Eng. Des., 50, 299-313 (2015).

36. L. P. Pook, "A 50 year retrospective review of three-dimensional effects at cracks and sharp notches," Fatigue Fract. Eng. Mater. Struct., 36, 699-723 (2013).

37. Z. Yosibash, A. Bussiba, and I. Gilad, "Failure criteria for brittle elastic materials," Int. J. Fracture, 125, No. 3, 307-333 (2004).

38. P. Lazzarin, F. Berto, and M. Zappalorto, "Rapid calculations of notch stress intensity factors based on averaged strain energy density from coarse meshes: Theoretical bases and applications," Int. J. Fatigue, 32, 1559-1567 (2010).

39. P. Lazzarin, F. Berto, F. Gomez, and M. Zappalorto, "Some advantages derived from the use of the strain energy density over a control volume in fatigue strength assessments of welded joints," Int. J. Fatigue, 30, 1345-1357 (2008). 